\title{
Targeting Histamine Receptors in Irritable Bowel Syndrome: A Critical Appraisal
}

\author{
Adam Fabisiak, ${ }^{1}$ Jakub Włodarczyk, ${ }^{1}$ Natalia Fabisiak, ${ }^{1}$ Martin Storr, ${ }^{2,3}$ and Jakub Fichna ${ }^{1 *}$ \\ ${ }^{I}$ Department of Biochemistry, Faculty of Medicine, Medical University of Lodz, Lodz, Poland, ${ }^{2}$ Center of Endoscopy, Starnberg; Germany; and \\ ${ }^{3}$ Walter Brendel Center of Experimental Medicine, Ludwig Maximilians University of Munich, Munich, Germany
}

Irritable bowel syndrome is a group of functional gastrointestinal disorders with not yet fully clarified etiology. Recent evidence suggesting that mast cells may play a central role in the pathogenesis of irritable bowel syndrome paves the way for agents targeting histamine receptors as a potential therapeutic option in clinical treatment. In this review, the role of histamine and histamine receptors is debated. Moreover, the clinical evidence of anti-histamine therapeutics in irritable bowel syndrome is discussed.

(J Neurogastroenterol Motil 2017;23:341-348)

\section{Key Words}

Ebastine; Irritable bowel syndrome; Mast cells; Receptors, histamine

\section{Introduction}

Irritable bowel syndrome (IBS) is a functional gastrointestinal (GI) disorder without completely elucidated etiology. The typical symptoms are abdominal pain and change in bowel habits. Additionally, bloating, tenesmus, bowel urgency, and abdominal distension can occur. A recent meta-analysis estimated the international prevalence of IBS at $11.2 \%^{1}$ based on the Rome III criteria; however, a recent study in China showed that the number of patients diagnosed based on the Rome IV criteria is nearly half the number of patients diagnosed according to the Rome III criteria. ${ }^{2}$ However, only one-third of those who suffer from IBS-like symptoms see a physician, the actual prevalence may be much higher. IBS impairs the quality of life in patients to a similar degree as in patients with inflammatory bowel diseases ${ }^{3}$ and the impairment is proportional to the severity of the symptoms experienced by the patient. ${ }^{4}$

IBS is a heterogeneous entity with etiology comprising of multiple factors such as inflammation, neuroimmune interactions, ${ }^{5}$ gut microbiota, ${ }^{6}$ environmental pollution, ${ }^{7}$ and abnormal gut-brain axis. ${ }^{8}$ This heterogeneity has a significant impact on treatment. As the disease profile may vary between the patients, the treatment should be personally tailored with regard to predominant symptoms and disease characteristics. It is particularly crucial due to the plethora of drugs available on the market nowadays. ${ }^{9}$ However, despite the number of drugs available the treatments are not fully satisfactory in all patients. Also, the symptoms eventually relapse.

A large portion of both established and investigated treatment options include drugs based on serotonin (5-hydroxytryptamine, 5-HT). Indeed, 5-HT plays an important role in the gut by affecting motility and secretion. ${ }^{10}$ Moreover, it was recently found that alterations in 5-HT metabolism may be implicated in visceral hy-

Received: November 24, 2016 Revised: March 10, 2017 Accepted: April 7, 2017

(a) This is an Open Access article distributed under the terms of the Creative Commons Attribution Non-Commercial License (http://creativecommons. org/licenses/by-nc/4.0) which permits unrestricted non-commercial use, distribution, and reproduction in any medium, provided the original work is properly cited.

*Correspondence: Jakub Fichna, PhD, DSc

Department of Biochemistry, Faculty of Medicine, Medical University of Lodz, Mazowiecka 6/8, 92-215 Lodz, Poland

Tel: +48-42-272-5707, Fax: +48-42-272-5694, E-mail: jakub.fichna@umed.lodz.pl

Adam Fabisiak and Jakub Włodarczyk contributed equally to this work. 
persensitivity, which is an important feature of IBS. ${ }^{11}$ Interestingly, in a study performed by Cremon et $\mathrm{al}^{12}$ the lamina propria mast cell (MC) count positively correlates with the increase in spontaneous 5-HT release in patients with IBS. While serotonin has already proven to be implicated in the pathogenesis of IBS, histamine is emerging as an important biogenic amine in this disease. Although the pathophysiological role of histamine in IBS is not entirely clear, there is evidence that supports the use of agents targeting the histamine receptors (HRs) as a potential therapeutic option in these patients. In this review, the role of histamine and HRs in IBS is critically appraised. Moreover, the possible use of anti-histamine therapeutics is discussed.

\section{Overview of Histamine and Histamine Receptors in the Gastrointestinal Tract}

Histamine (2-[4-imidazolyl]-ethylamine) is a short-acting endogenous amine, which is widely distributed in the human body. ${ }^{13}$ Histamine is synthesized by the enzyme histidine decarboxylase in all human tissues, but is particularly abundant in the skin, lungs, and GI tract. ${ }^{14}$

Histamine is produced mainly by MCs and, to a lesser extent, by basophils, gastric enterochromaffin-like cells, and histaminergic neurons. ${ }^{15,16}$ However, platelets, dendritic cells (DCs), T cells, and even microbes can also express histidine decarboxylase following a stimulation by cytokines, including IL-1, IL-3, IL-12, IL-18, granulocyte-macrophage colony-stimulating factor, macrophage colony-stimulating factor, and TNF- $\alpha .^{13,17,18}$ Only MCs and basophils are capable of storing large quantities of histamine. Other cell types such as DCs and lymphocytes do not store histamine intracellularly but the synthesis is followed by an immediate secretion.
Histamine is involved in several physiological functions, including cell proliferation and differentiation, hematopoiesis, regeneration, and the regulation of innate and adaptive immune systems. ${ }^{19}$ Histamine exerts its biological actions by binding to 4 subtypes of HRs, which are named chronologically in order of their discovery: $\mathrm{H}_{1} \mathrm{R}-\mathrm{H}_{4} \mathrm{R}$. These 4 binding sites belong to the rhodopsin-like family of $G$ protein-coupled receptors, which are differentially expressed in numerous cell types. Although all $4 \mathrm{HRs}$ are expressed in the human body, the intestines seem to be devoid of $\mathrm{H}_{3} \mathrm{Rs}^{20}{ }^{20}$ The expression pattern of HRs does not change anatomically along the intestine.

In the GI tract, histamine is believed to impact at least 3 major functions: modulation of GI motility, enhancement of gastric acid production, and alteration of mucosal ion secretion. ${ }^{21-23} \mathrm{H}_{1}$ Rs are involved in mediating sensorineural signaling and vascular dilatation. ${ }^{24}$ Activation of $\mathrm{H}_{1} \mathrm{R}$ is known to regulate food and water intake and diurnal feeding rhythm. ${ }^{25}$ Stimulation of $\mathrm{H}_{2} \mathrm{R}$ results in degranulation of MCs, synthesis of antibodies, production of $\mathrm{T}$ helper (Th) 1 cytokines, and T-cell proliferation. ${ }^{16,26} \mathrm{H}_{4} \mathrm{R}$ plays a significant role in nociception, autoimmune disorders, colon cancer, and allergy. ${ }^{27-29}$ Clear interpretation of histamine involvement in regulation of GI motility is currently lacking. However, the evidence indicates that overproduction of histamine by MCs may be responsible for diarrhea caused by increased neuronal secretomotor function. ${ }^{30}$ Another hypothesis assumes that in constipated patients histamine induces altered enteric neuron function as a result of an excessive segmental contractile colonic motor activity. ${ }^{31}$ However, the pathological relevance of increased histamine levels in diseases, such as IBS, is not yet fully elucidated.

Table 1 describes the localization and role of specific HRs in the GI tract. Localization of HRs in the intestinal wall is depicted

Table 1. Localization and Role of Specific Histamine Receptors in the Gastrointestinal Tract

\begin{tabular}{|c|c|c|}
\hline Receptors & Localization & Role \\
\hline $\mathrm{H} 1$ & $\begin{array}{l}\text { Enterocytes, connective tissue cells, immune cells, } \\
\text { blood vessels, myocytes, and myenteric plexus }\end{array}$ & $\begin{array}{l}\text { Regulation of diurnal feeding rhythm, mediation of sensorineural } \\
\text { signaling, control of vascular dilatation and permeability, impact } \\
\text { on gastrointestinal contractility and motility, and modulation of } \\
\text { visceral pain }\end{array}$ \\
\hline $\mathrm{H} 2$ & Enterocytes, immune cells, myocytes, and myenteric plexus & $\begin{array}{l}\text { Immunomodulatory properties and control of gastrointestinal } \\
\text { contractility and motility }\end{array}$ \\
\hline $\mathrm{H} 3$ & Not found in the human gastrointestinal tract & \\
\hline $\mathrm{H} 4$ & $\begin{array}{l}\text { Lamina propria mononuclear cells and intestinal mast cells, } \\
\text { leukocytes in mucosal and submucosal blood vessels, and } \\
\text { enterocytes in the apical end of intestinal glands }\end{array}$ & $\begin{array}{l}\text { Immunomodulatory properties, impact on gastrointestinal } \\
\text { contractility and motility, and modulation of visceral pain }\end{array}$ \\
\hline
\end{tabular}




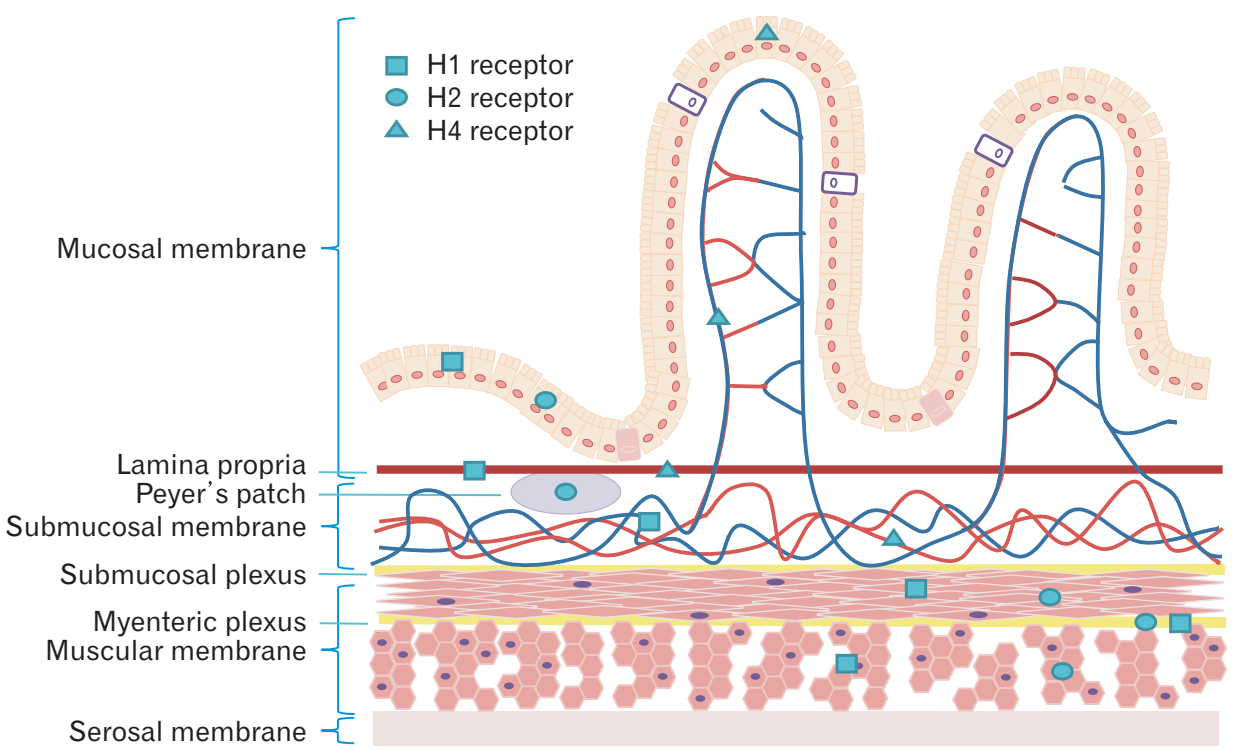

Figure. Localization of histamine receptors in the intestinal wall. in Figure.

\section{Irritable Bowel Syndrome and Histamine}

The summary on animal and human studies with MCs and HRs as targets is shown in Table 2.32-41

The etiology and the pathophysiology are only partly understood, with some evidence suggesting that intestinal infections, and dysfunctional mucosal immune responses may play a role in the development of IBS and its symptoms.

Patients with IBS frequently experience post-prandial worsening of their symptoms. Moreover, a vast majority of IBS patients feel that distinct foods play pivotal role in triggering their symptoms. In a recent study, $58 \%$ of patients with IBS experienced GI symptoms from histamine-releasing food items such as milk, wine or beer, and foods rich in biogenic amines (wine, beer, and cheese). Interestingly, the use of spherical carbon adsorbents, known for adsorbing molecules (for instance histamine) from the gut lumen has been proven to be beneficial in some patients. ${ }^{41}$

High levels of histamine were found in supernatants from IBS colonic samples. ${ }^{43}$ Application of this supernatant to rat submucous neurons resulted in increased neuronal activity. Furthermore, positive correlation between histamine levels in the supernatant and the degree of activation was stated. ${ }^{44}$ The neuronal response of submucous neurons to the artificially designed cocktail, which is a combination of mucosal and immune mediators mimicking nerve activating components found in colonic biopsy supernatants and serum of IBS-patients, was lower in mucosal IBS biopsies compared to healthy controls. ${ }^{45}$ This effect appears in IBS most likely due to the desensitization to mediators, which is caused by the chronic contact of the gut wall with the mediators found in the gut lumen. Additionally, histamine induced murine jejunal afferent firing and excited primary sensory neurons. ${ }^{46,47}$ According to the study of Barbara et $\mathrm{al}^{43}$ the pronociceptive effect of histamine appears to be mediated, at least partly, by $\mathrm{H}_{1} \mathrm{R}$ expressed on sensory afferents. In contrast, Guarino et $\mathrm{al}^{48}$ found that supernatants from patients with IBS impair contractility of isolated human colonic smooth muscles and the phenomenon is histamine-independent. The effect was significantly reversible by apocynin, a nicotinamide adenine dinucleotide phosphate (NADPH) oxidase inhibitor, suggesting the intracellular oxidative stress damage to be the main cause of this contractility impairment.

The expression of $\mathrm{H}_{1} \mathrm{R}$ and $\mathrm{H}_{2} \mathrm{R}$ in the intestinal tissue samples of IBS patients is upregulated. ${ }^{20}$ Moreover, it has been reported that $\mathrm{H}_{1} \mathrm{R}$ activation results in proinflammatory effects such as IFN production and Th1 cell proliferation, while $\mathrm{H}_{2} \mathrm{R}$ activation appears to suppress inflammation. ${ }^{19,49,50}$ Activation of $\mathrm{H}_{2} \mathrm{R}$ by histamine suppresses IL-12 production by monocytes, ${ }^{51} \mathrm{IFN}-\gamma$ production by macrophages, ${ }^{52}$ TNF- $\alpha$ secretion by MCs, ${ }^{53}$ and IL-12 release by immature DCs. ${ }^{54}$ In vivo studies showed that histamine suppresses both Th1- and Th2-type responses by $\mathrm{H}_{2} \mathrm{R} .{ }^{55}$ It is noteworthy that in colonic biopsies of IBS patients or patients with food allergy, no alterations in $\mathrm{H}_{4} \mathrm{R}$ mRNA levels were reported. ${ }^{20}$ However, involvement of the $\mathrm{H}_{4} \mathrm{R}$ in visceral sensory signaling and $\mathrm{GI}$ contractility has been documented ${ }^{56}$; yet, more studies are needed to fully elucidate the contribution of $\mathrm{H}_{4} \mathrm{R}$ in IBS. 


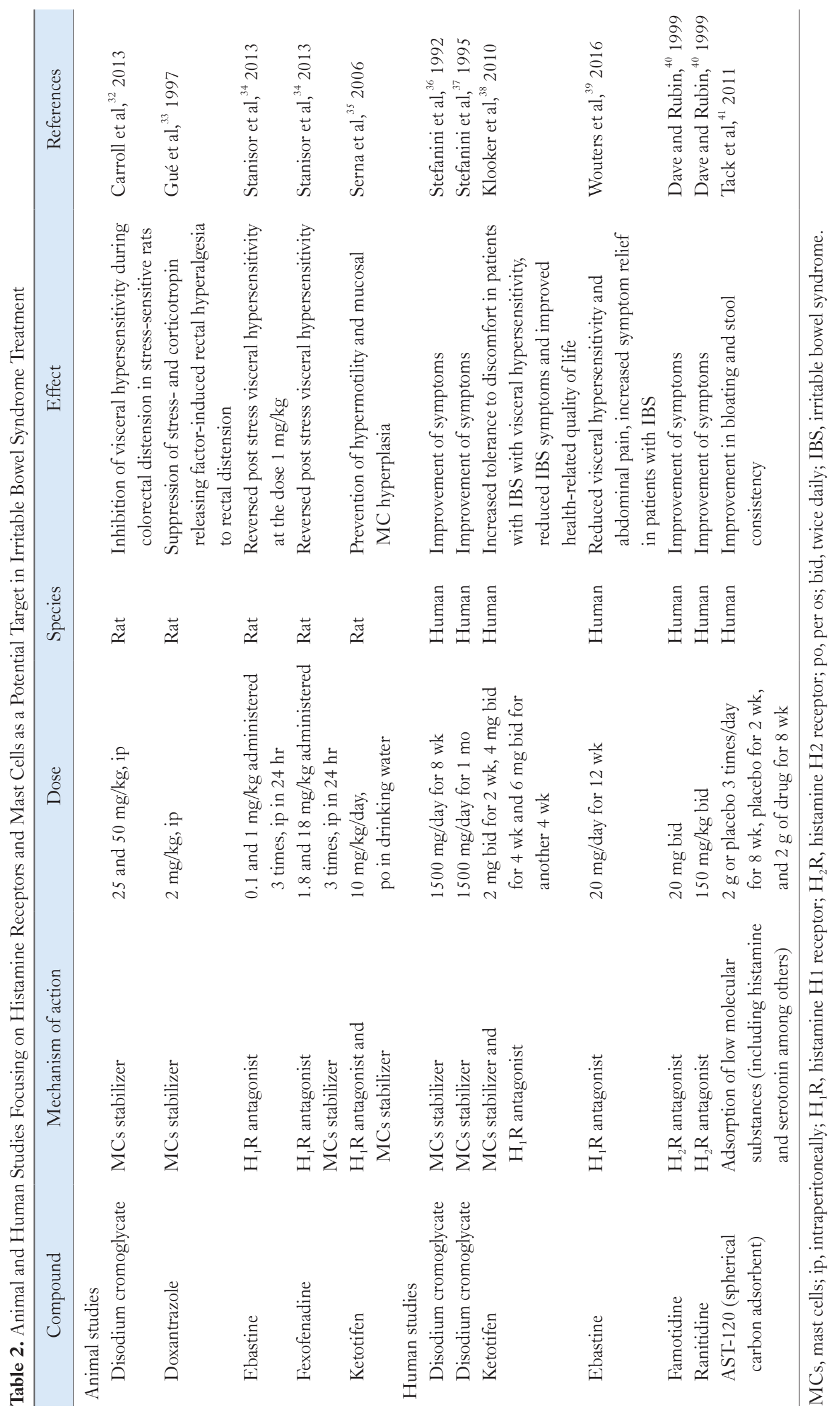


There is a large body of evidence suggesting that MCs are an important factor in the pathophysiology of IBS. ${ }^{39}$ IBS patients have an increased number of MCs, which contain granules rich in mediators such as histamine, tryptase, and nerve growth factors that can activate and sensitize enteric nerves, and modulate the integrity of the epithelial barrier. ${ }^{57,58}$ An increased number of mucosal MCs has been observed in biopsy samples from the rectum, ${ }^{59}$ rectosigmoid, ${ }^{60}$ descending colon, ${ }^{43}$ ascending colon, ${ }^{59}$ cecum, ${ }^{61}$ terminal ileum, ${ }^{59}$ jejunum, ${ }^{62}$ and duodenum ${ }^{63}$ of patients with IBS. Also, the level of activation and intensity of MCs degranulation is increased. Activated MCs spontaneously secreting higher amounts of histamine in close proximity to colonic nerves correlated with severity and frequency of abdominal pain in IBS patients. ${ }^{31}$ According to the study of Cremon et $\mathrm{al}^{64}$ it is possible that the number of functionally active MCs is more important in IBS, rather than the absolute number of cells. The recent review by Zhang et $\mathrm{al}^{65}$ profoundly embraces all aspects of MCs in IBS.

\section{Possible Application of Anti-histamine Drugs in Irritable Bowel Syndrome}

Abdominal pain, often described as discomfort, is believed to be linked to visceral hypersensitivity which seems to be multifactorial. ${ }^{66,67} \mathrm{MCs}$ and histamine seem to contribute majorly to visceral hypersensitivity. A study on $\mathrm{H}_{1} \mathrm{R}$ knockout mice showed that they are more prone to visceral pain, measured by abdominal stretching after intraperitoneal injection of either acetic acid or $\mathrm{MgSO}_{4}$ than their wild type littermates. ${ }^{68} \mathrm{~A}$ study in the rat model of IBS induced by acetic acid revealed a higher degranulation rate of MCs in the colon from rats with IBS-like symptoms. Moreover, pretreatment with a MC stabilizer, doxantrazole, decreased visceral sensory response to rectal distention in these rats. ${ }^{69}$ Finally, histamine was shown to activate enteric neurons through $\mathrm{H} 1$ and $\mathrm{H} 2$ receptors. $^{70,71}$

MCs with their stored enzymes are important players in dysregulated brain-gut axis. Thus, targeting MCs or HRs arises as a potent treatment option for selected patients with IBS. A few clinical studies have addressed this hypothesis. Klooker et al ${ }^{38}$ attempted to translate the research on the use of MC stabilizers in IBS from animals ${ }^{33}$ to humans. The randomized double-blinded controlled trial showed that ketotifen increased tolerance to abdominal discomfort in patients with IBS with visceral hypersensitivity, improved symptoms and the quality of life. However, no effect on the number of MCs, release of tryptase and histamine from rectal biopsies could be demonstrated. Since ketotifen is a $\mathrm{H} 1$ receptor antagonist, an MC stabilizer, a phosphodiesterase inhibitor and a functional leukotriene inhibitor, it was not completely evident which of its features was responsible for the anti-IBS effects. Therefore, MC stabilization and $\mathrm{H}_{1} \mathrm{R}$ blockade could be further explored as potential new treatments for IBS.

A recent study showed that by blocking $\mathrm{H}_{1} \mathrm{R}$ with ebastine, a second generation $\mathrm{H}_{1} \mathrm{R}$ antagonist, attenuation of visceral hypersensitivity and other IBS symptoms could be achieved. ${ }^{39}$ Interestingly, the transient receptor potential vanilloid 1 (TRPV1) was found to be implicated in the process; either histamine alone or the supernatant from rectal biopsies from patients with IBS sensitize TRPV1 channels. Upon activation by stimuli such as noxious heat, acidosis or endovanilloids, TRPV1 becomes non-selectively permeable for ions. It is most likely that sensitization lowers the threshold for channel activation possibly leading to activation by the normal body temperature. The involvement of TRPV1 in IBS has been investigated before. Akbar et $\mathrm{al}^{60}$ discovered increased sensory fibers which express TRPV1 channel in patients with IBS. Also, the results from animal studies suggested the contribution of TRPV1 in visceral hypersensitivity. ${ }^{72,73}$ However, TRPV1 is distinctive, involved in both physiological and pathophysiological actions in the human body, such as maintaining proper lower urinary tract function. $^{74}$ Thus, prior to the discovery of a crosstalk between MCs and TRPV1, it was unreasonable to talk about the TRPV1 as a standalone therapeutic target. Now, as the connection between the two became apparent, it is easier to indicate plausible therapeutic agents.

The aforementioned HR antagonists are without doubt a part of that group with ebastine in the lead. Ebastine is a secondgeneration $\mathrm{H}_{1} \mathrm{R}$ antagonist free of any significant influence on the central nervous system as it does not penetrate the blood-brain barrier. ${ }^{75}$ The occurrence rate of the most common adverse events such as drowsiness, headache and dry mouth is comparable to placebos. Ebastine showed a satisfactory utility in abating the symptoms of allergic rhinitis and chronic idiopathic urticaria. ${ }^{75}$ Smaller studies also indicate its possible use in cold urticaria, atopic asthma, mosquito bites, and the common cold (with pseudoephedrine). ${ }^{76-79}$ Additional advantages include the once-daily administration, pharmacokinetics independent of food intake, and availability of a novel formulation — fast dissolving tablet—which does not require the aid of a drink. Currently, there is an ongoing multicenter trial assessing the efficacy of ebastine in patients with IBS (ClinicalTrials.gov Identifier: NCT01908465). 


\section{Conclusions and Future Perspectives}

The following questions remain unanswered: should we focus more on histamine receptors in IBS? The answer cannot come as a simple binary result but requires further elaboration. We already use MCs as a target, though in a rather indirect way. McIntosh et $\mathrm{al}^{80}$ recently reported that diets low in fermentable oligosaccharides, disaccharides, mono-saccharides, and polyols (FODMAPs) changes the metabolome, significantly reducing histamine levels in the urine. Consequently, by administering the diet low in FODMAPs we could modulate the histamine levels in patients with IBS thus altering the symptoms. Although histamine is not the only mediator found to be implicated in the pathogenesis of IBS, it is evident that this biogenic amine is pathologically of great importance.

In conclusion, HR antagonists are definitely worth being considered as potential therapeutic agents in treating IBS, especially the second generation agents which lack activity in the central nervous system, but display a considerably safe profile. Larger studies on ebastine will reveal the efficacy of $\mathrm{H}_{1} \mathrm{R}$ antagonists in patients with IBS. For other HR compounds like ketotifen, famotidine, ranitidine, and AST-120, there is already evidence from clinical trials in patients with IBS that suggest that their use may be beneficial. However, until the mechanisms of action of these compounds are elucidated the possibility of using HRs-targeting agents remains speculative.

Financial support: This study was supported by the Medical University of Lodz (Project UMED Grant No. 564/1-00000/564-20-010 to Adam Fabisiak and 503/1-156-04/503-11-001 to Jakub Włodarczyk).

\section{Conflicts of interest: None.}

Author contributions: collecting and interpreting data: Adam Fabisiak, Jakub Włodarczyk, and Natalia Fabisiak; drafting the manuscript: Adam Fabisiak, Jakub Włodarczyk, and Natalia Fabisiak; critical revision: Martin Storr; and Jakub Fichna was responsible for all aspects of the manuscript.

\section{References}

1. Lovell RM, Ford AC. Global Prevalence of and Risk Factors for Irritable Bowel Syndrome: A Meta-analysis. Clin Gastroenterol Hepatol 2012;10:712-721, e4.
2. Bai T, Xia J, Jiang Y, et al. Comparison of the Rome IV and Rome III criteria for IBS diagnosis: a cross-sectional survey. J Gastroenterol Hepatol. 2017;32:1018-1025.

3. Pace F, Molteni P, Bollani S, et al. Inflammatory bowel disease versus irritable bowel syndrome: a hospital-based, case-control study of disease impact on quality of life. Scand J Gastroenterol 2003;38:1031-1038.

4. Monnikes H. Quality of life in patients with irritable bowel syndrome. J Clin Gastroenterol 2011;45(suppl):S98-S101.

5. Ohman L, Simrén M. Pathogenesis of IBS: role of inflammation, immunity and neuroimmune interactions. Nat Rev Gastroenterol Hepatol 2010;7:163-173.

6. Distrutti E, Monaldi L, Ricci P, Fiorucci S. Gut microbiota role in irritable bowel syndrome: new therapeutic strategies. World J Gastroenterol 2016;22:2219-2241.

7. Marynowski M, Likońska A, Zatorski H, Fichna J. Role of environmental pollution in irritable bowel syndrome. World J Gastroenterol 2015;21:11371-11378.

8. Fichna J, Storr MA. Brain-gut interactions in IBS. Front Pharmacol 2012;3:127.

9. Mosińska P, Salaga M, Fichna J. Novel investigational drugs for constipation-predominant irritable bowel syndrome: a review. Expert Opin Investig Drugs 2016;25:275-286.

10. Gershon MD. Review article: serotonin receptors and transporters--roles in normal and abnormal gastrointestinal motility. Aliment Pharmacol Ther 2004;20(suppl 7):3-14.

11. Keszthelyi D, Troost FJ, Jonkers DM, et al. Visceral hypersensitivity in irritable bowel syndrome: evidence for involvement of serotonin metabolism--a preliminary study. Neurogastroenterol Motil 2015;27:1127-1137.

12. Cremon C, Carini G, Wang B, et al. Intestinal serotonin release, sensory neuron activation, and abdominal pain in irritable bowel syndrome. Am J Gastroenterol 2011;106:1290-1298.

13. Jutel M, Akdis M, Akdis CA. Histamine, histamine receptors and their role in immune pathology. Clin Exp Allergy 2009;39:1786-1800.

14. Wouters MM. Histamine antagonism and postinflammatory visceral hypersensitivity. Gut 2014;63:1836-1837.

15. Akdis CA, Blaser K. Histamine in the immune regulation of allergic inflammation. J Allergy Clin Immunol 2003;112:15-22.

16. Jutel M, Watanabe T, Akdis M, Blaser $\mathrm{K}$, Akdis CA. Immune regulation by histamine. Curr Opin Immunol 2002;14:735-740.

17. Dy M, Schneider E. Histamine-cytokine connection in immunity and hematopoiesis. Cytokine Growth Factor Rev 2004;15:393-410.

18. Schneider E, Rolli-Derkinderen M, Arock M, Dy M. Trends in histamine research: new functions during immune responses and hematopoiesis. Trends Immunol 2002;23:255-263.

19. Smolinska S, Jutel M, Crameri R, O'Mahony L. Histamine and gut mucosal immune regulation. Allergy 2014;69:273-281.

20. Sander LE, Lorentz A, Sellge G, et al. Selective expression of histamine receptors $\mathrm{H} 1 \mathrm{R}, \mathrm{H} 2 \mathrm{R}$, and $\mathrm{H} 4 \mathrm{R}$, but not $\mathrm{H} 3 \mathrm{R}$, in the human intestinal tract. Gut 2006;55:498-504.

21. Tanaka S, Hamada K, Yamada N, et al. Gastric acid secretion in Lhistidine decarboxylase-deficient mice. Gastroenterology 2002;122:145155 
22. Fargeas MJ, Fioramonti J, Bueno L. Involvement of different receptors in the central and peripheral effects of histamine on intestinal motility in the rat. J Pharm Pharmacol 1989;41:534-540.

23. Keely SJ, Stack WA, O'Donoghue DP, Baird AW. Regulation of ion transport by histamine in human colon. Eur J Pharmacol 1995;279:203209.

24. Togias A. H1-receptors: localization and role in airway physiology and in immune functions. J Allergy Clin Immunol 2003;112(suppl):S60-S68.

25. Masaki T, Yoshimatsu H. The hypothalamic H1 receptor: a novel therapeutic target for disrupting diurnal feeding rhythm and obesity. Trends Pharmacol Sci 2006;27:279-284.

26. Meiler F, Zumkehr J, Klunker S, Rückert B, Akdis CA, Akdis M. In vivo switch to IL-10-secreting $\mathrm{T}$ regulatory cells in high dose allergen exposure. J Exp Med 2008;205:2887-2898.

27. Thurmond RL, Desai PJ, Dunford PJ, et al. A potent and selective histamine $\mathrm{H} 4$ receptor antagonist with anti-inflammatory properties. J Pharmacol Exp Ther 2004;309:404-413.

28. Varga C, Horvath K, Berko A, Thurmond RL, Dunford PJ, Whittle $\mathrm{BJ}$. Inhibitory effects of histamine $\mathrm{H} 4$ receptor antagonists on experimental colitis in the rat. Eur J Pharmacol 2005;522:130-138.

29. Cianchi F, Cortesini C, Schiavone N, et al. The role of cyclooxygenase-2 in mediating the effects of histamine on cell proliferation and vascular endothelial growth factor production in colorectal cancer. Clin Cancer Res 2005;11(19 Pt 1):6807-6815.

30. Wood JD. Neuropathophysiology of irritable bowel syndrome. J Clin Gastroenterol 2002;35(suppl 1):S11-S22.

31. Barbara G, Stanghellini V, De Giorgio R, et al. Activated mast cells in proximity to colonic nerves correlate with abdominal pain in irritable bowel syndrome. Gastroenterology 2004;126:693-702.

32. Carroll SY, O’Mahony SM, Grenham S, Cryan JF, Hyland NP. Disodium cromoglycate reverses colonic visceral hypersensitivity and influences colonic ion transport in a stress-sensitive rat strain. PLoS One 2013;8:e84718

33. Gué M, Del Rio-Lacheze C, Eutamene H, Théodorou V, Fioramonti J, Buéno L. Stress-induced visceral hypersensitivity to rectal distension in rats: role of CRF and mast cells. Neurogastroenterol Motil 1997;9:271279.

34. Stanisor OI, van Diest SA, Yu Z, et al. Stress-induced visceral hypersensitivity in maternally separated rats can be reversed by peripherally restricted histamine-1-receptor antagonists. PLoS One 2013;8:e66884.

35. Serna H, Porras M, Vergara P. Mast cell stabilizer ketotifen [4-(1-Methyl-4-piperidylidene)-4H-benzo [4,5] cyclohepta [1,2-b] thiophen$10(9 \mathrm{H})$-one Fumarate] prevents mucosal mast cell hyperplasia and intestinal dysmotility in experimental Trichinella spiralis inflammation in the rat. J Pharmacol Exp Ther 2006;319:1104-1111.

36. Stefanini GF, Prati E, Albini MC, et al. Oral disodium cromoglycate treatment on irritable bowel syndrome: an open study on 101 subjects with diarrheic type. Am J Gastroenterol 1992;87:55-57.

37. Stefanini GF, Saggioro A, Alvisi V, et al. Oral cromolyn sodium in comparison with elimination diet in the irritable bowel syndrome, diarrheic type. Multicenter study of 428 patients. Scand J Gastroenterol 1995;30:535-541.
38. Klooker TK, Braak B, Koopman KE, et al. The mast cell stabiliser ketotifen decreases visceral hypersensitivity and improves intestinal symptoms in patients with irritable bowel syndrome. Gut 2010;59:1213-1221.

39. Wouters MM, Balemans D, Van Wanrooy S, et al. Histamine receptor H1-mediated sensitization of TRPV1 mediates visceral hypersensitivity and symptoms in patients with irritable bowel syndrome. Gastroenterology 2016;150:875-887.

40. Dave B, Rubin W. Inhibition of gastric secretion relieves diarrhea and postprandial urgency associated with irritable bowel syndrome or functional diarrhea. Dig Dis Sci 1999;44:1893-1898.

41. Tack JF, Miner PB Jr, Fischer L, Harris MS. Randomised clinical trial: the safety and efficacy of AST-120 in non-constipating irritable bowel syndrome - a double-blind, placebo-controlled study. Aliment Pharmacol Ther 2011;34:868-877.

42. Böhn L, Störsrud S, Törnblom H, Bengtsson U, Simrén M. Selfreported food-related gastrointestinal symptoms in IBS are common and associated with more severe symptoms and reduced quality of life. Am J Gastroenterol 2013;108:634-641.

43. Barbara G, Wang B, Stanghellini V, et al. Mast cell-dependent excitation of visceral-nociceptive sensory neurons in irritable bowel syndrome. Gastroenterology 2007;132:26-37.

44. Buhner S, Schemann M. Mast cell-nerve axis with a focus on the human gut. Biochim Biophys Acta 2012;1822:85-92.

45. Ostertag D, Buhner S, Michel K, et al. Reduced responses of submucous neurons from irritable bowel syndrome patients to a cocktail containing histamine, serotonin, $\mathrm{TNF} \alpha$, and tryptase (IBS-cocktail). Front Neurosci 2015;9:465.

46. Kreis ME, Haupt W, Kirkup AJ, Grundy D. Histamine sensitivity of mesenteric afferent nerves in the rat jejunum. Am J Physiol 1998;275(4 Pt 1):G675-G680.

47. Brunsden AM, Grundy D. Sensitization of visceral afferents to bradykinin in rat jejunum in vitro. J Physiol 1999;521(Pt 2):517-527.

48. Guarino MP, Barbara G, Cicenia A, et al. Supernatants of irritable bowel syndrome mucosal biopsies impair human colonic smooth muscle contractility. Neurogastroenterol Motil 2017;29:e12928

49. O'Mahony L, Akdis M, Akdis CA. Regulation of the immune response and inflammation by histamine and histamine receptors. J Allergy Clin Immunol 2011;128:1153-1162.

50. Frei R, Ferstl R, Konieczna P, et al. Histamine receptor 2 modifies dendritic cell responses to microbial ligands. J Allergy Clin Immunol 2013;132:194-204.

51. Elenkov IJ, Webster E, Papanicolaou DA, Fleisher TA, Chrousos GP, Wilder RL. Histamine potently suppresses human IL-12 and stimulates IL-10 production via H2 receptors. J Immunol 1998;161:2586-2593.

52. Horváth B V, Szalai C, Mándi Y, et al. Histamine and histamine-receptor antagonists modify gene expression and biosynthesis of interferon gamma in peripheral human blood mononuclear cells and in CD19-depleted cell subsets. Immunol Lett 1999;70:95-99.

53. Bissonnette EY. Histamine inhibits tumor necrosis factor alpha release by mast cells through $\mathrm{H} 2$ and $\mathrm{H} 3$ receptors. Am J Respir Cell Mol Biol 1996;14:620-626.

54. Mazzoni A, Young HA, Spitzer JH, Visintin A, Segal DM. Histamine 
regulates cytokine production in maturing dendritic cells, resulting in altered T cell polarization. J Clin Invest 2001;108:1865-1873.

55. Jutel M, Watanabe T, Klunker S, et al. Histamine regulates T-cell and antibody responses by differential expression of $\mathrm{H} 1$ and $\mathrm{H} 2$ receptors. Nature 2001;413:420-425.

56. Deiteren A, De Man JG, Pelckmans PA, De Winter BY. Histamine H4 receptors in the gastrointestinal tract. Br J Pharmacol 2015;172:11651178.

57. van Wanrooij SJ, Wouters MM, Van Oudenhove L, et al. Sensitivity testing in irritable bowel syndrome with rectal capsaicin stimulations: role of TRPV1 upregulation and sensitization in visceral hypersensitivity? Am J Gastroenterol 2014;109:99-109.

58. Piche T, Barbara G, Aubert P, et al. Impaired intestinal barrier integrity in the colon of patients with irritable bowel syndrome: involvement of soluble mediators. Gut 2009;58:196-201.

59. Park JH, Rhee PL, Kim HS, et al. Mucosal mast cell counts correlate with visceral hypersensitivity in patients with diarrhea predominant irritable bowel syndrome. J Gastroenterol Hepatol 2006;21(1 Pt 1):71-78.

60. Akbar A, Yiangou Y, Facer P, Walters JR, Anand P, Ghosh S. Increased capsaicin receptor TRPV1-expressing sensory fibres in irritable bowel syndrome and their correlation with abdominal pain. Gut 2008;57:923929.

61. Vivinus-Nébot M, Dainese R, Anty R, et al. Combination of allergic factors can worsen diarrheic irritable bowel syndrome: role of barrier defects and mast cells. Am J Gastroenterol 2012;107:75-81.

62. Guilarte M, Santos J, de Torres I, et al. Diarrhoea-predominant IBS patients show mast cell activation and hyperplasia in the jejunum. Gut 2007;56:203-209.

63. Schemann M, Camilleri M. Functions and imaging of mast cell and neural axis of the gut. Gastroenterology 2013;144:698-704.

64. Cremon C, Gargano L, Morselli-Labate AM, et al. Mucosal immune activation in irritable bowel syndrome: gender-dependence and association with digestive symptoms. Am J Gastroenterol 2009;104:392-400.

65. Zhang L, Song J, Hou X. Mast cells and irritable bowel syndrome: from the bench to the bedside. J Neurogastroenterol Motil 2016;22:181-192.

66. Deiteren A, de Wit A, van der Linden L, De Man JG, Pelckmans PA, De Winter BY. Irritable bowel syndrome and visceral hypersensitivity : risk factors and pathophysiological mechanisms. Acta Gastroenterol Belg 2016;79:29-38.

67. De Winter BY, Deiteren A, De Man JG. Novel nervous system mechanisms in visceral pain. Neurogastroenterol Motil 2016;28:309-315.
68. Mobarakeh JI, Sakurada S, Katsuyama S, et al. Role of histamine $\mathrm{H}_{1}$ receptor in pain perception: a study of the receptor gene knockout mice. Eur J Pharmacol 2000;391:81-89.

69. La JH, Kim TW, Sung TS, Kim HJ, Kim JY, Yang IS. Role of mucosal mast cells in visceral hypersensitivity in a rat model of irritable bowel syndrome. J Vet Sci 2004;5:319-324.

70. Fu LW, Pan HL, Longhurst JC. Endogenous histamine stimulates ischemically sensitive abdominal visceral afferents through $\mathrm{H}_{1}$ receptors. Am J Physiol 1997;273:H2726-H2737.

71. Liu S, Hu HZ, Gao N, et al. Neuroimmune interactions in guinea pig stomach and small intestine. Am J Physiol Gastrointest Liver Physiol 2003;284:G154-G164.

72. Winston J, Shenoy M, Medley D, Naniwadekar A, Pasricha PJ. The vanilloid receptor initiates and maintains colonic hypersensitivity induced by neonatal colon irritation in rats. Gastroenterology 2007;132:615-627.

73. van den Wijngaard RM, Klooker TK, Welting O, et al. Essential role for TRPV1 in stress-induced (mast cell-dependent) colonic hypersensitivity in maternally separated rats. Neurogastroenterol Motil 2009;21:1107e94.

74. Pingle SC, Matta JA, Ahern GP. Capsaicin receptor: TRPV1 a promiscuous TRP channel. In: Transient receptor potential (TRP) channels. Springer Berlin Heidelberg 2007:155-171.

75. Sastre J. Ebastine in allergic rhinitis and chronic idiopathic urticaria. Allergy 2008;63(suppl 89):1-20.

76. Magerl M, Schmolke J, Siebenhaar F, Zuberbier T, Metz M, Maurer M. Acquired cold urticaria symptoms can be safely prevented by ebastine. Allergy 2007;62:1465-1468.

77. Wood-Baker R, Holgate ST. Dose-response relationship of the H1histamine antagonist, ebastine, against histamine and methacholineinduced bronchoconstriction in patients with asthma. Agents Actions 1990;30:284-286.

78. Karppinen A, Petman L, Jekunen A, Kautiainen H, Vaalasti A, Reunala T. Treatment of mosquito bites with ebastine: a field trial. Acta Derm Venereol 2000;80:114-116.

79. Common Cold Collaborative Group, Robert M, Llorens M, García E, Luria X. Efficacy and tolerability of ebastine $10 \mathrm{mg}$ plus pseudoephedrine $120 \mathrm{mg}$ in the symptomatic relief of the common cold. Eur J Intern Med 2004;15:242-247.

80. McIntosh K, Reed DE, Schneider T, et al. FODMAPs alter symptoms and the metabolome of patients with IBS: a randomised controlled trial. Gut 2017;66:1241-1251. 